\title{
The vulnerability of past societies to climatic variation: a new focus for historical climatology in the twenty-first century
}

\author{
Christian Pfister
}

Received: 9 March 2010 / Accepted: 9 March 2010 / Published online: 19 May 2010

(C) Springer Science+Business Media B.V. 2010

\section{Introduction}

The field of historical climatology is situated at the interface between climatology and (environmental) history, and deals mainly with documentary evidence employing the methods of both climatology and history. It has three major objectives. These are: (a) reconstructing of weather and climate prior to the modern instrumental period, (b) investigating the vulnerability of past economies and societies to climatic extremes and natural disasters, and (c) exploration of discourses on climate (Pfister 2001; Brázdil et al. 2005, 2010). These three objectives developed very unevenly over the last 40 years. Historical climatologists directed most of their time and effort on collecting of documentary data and reconstructing past climate, mostly on the basis of differences between mean values of temperature during the "Little Ice Age" and those that prevail today. Progress in climate reconstruction was spurred through ESF and EU projects from the early 1990s, which allowed hitherto isolated researchers to collaborate in international team-based research. For a long-time climate, reconstructions from documentary data suffered as a result of employing statistically limited method (Dobrovolný et al. 2009a; Mauelshagen 2010). Substantial progress in this direction has recently been achieved by the European Union 6th Framework Program Integrated Project "Millennium"-European climate of the last Millennium (http://ralph.swan.ac.uk/millennium/). Several papers which appeared in the past years (e.g. Leijonhufvud et al. 2008, 2009; Dobrovolný et al. 2009a, b) have been successful in applying standard paleoclimatological approach (Cook et al. 1994) working with overlapping periods between proxy and instrumental data that are then used for calibration and verification purposes. These recent reconstructions are directly comparable with reconstructions based on other natural climate proxies. A great number of such reconstructions have been published in

C. Pfister $(\bowtie)$

Oeschger Center for Climatic Change Research, Institute of History, University of Bern, Unitobler, 3000, Bern 9, Switzerland

e-mail: christian.pfister@hist.unibe.ch 
Climatic Change which thus served as the main platform for disseminating findings from the field "historical climatology" (Brázdil et al. 2005, 2010).

When the greenhouse warming problem became an issue from the 1990s, the study of present and possible future climatic impacts on humankind also developed into a well-funded area of research alongside that of climate reconstructions. One would expect that this train of events might have stimulated "historical climatology" to embark on investigations about the climatic vulnerability experienced by past societies. However, this field has received so far very limited attention. A browsing of 500 papers published in Climatic Change yielded less than a dozen articles in which either the vulnerability of past societies prior to the Modern Instrumental Period or past social representations and memories of climate were addressed (e.g. Behringer 1999; Diaz and Stehle 2007; Endfield 2007; Perch-Nielsen et al. 2008; Ka-wai-Fan 2009; Pfister et al. 2010). Admittedly, interdisciplinary disaster research together with social scientific studies became increasingly attractive for historians in the wake of the International Decade of Natural Disaster Reduction in the 1990s; but climatic aspects remained marginal to the debates and most of the relevant papers were published in social science journals (Schenk and Engels 2007; Mauelshagen 2010). For this reason my editorial asks why the studies of past societies related to climate variations have hitherto remained marginal in historical climatology when compared to climate reconstructions. Subsequently, I will argue why historical climatologists should put a new focus on societal aspects of past climate variations.

The influential "History of Climate" of Emmanuel Le Roy Ladurie (1971) is the most appropriate point of departure for the discussion. The French historian became aware in the 1960s that geographers and physicists were taking an interest in the evidence on past climate offered by historical documents. He discovered a suitable proxy for assessing temperature in the warm season in the form of long, continuous, quantitative and relatively homogenous series about the timing of vine harvests. Having been a student of Fernand Braudel (1902-1985), the French historian wrote his history of climate according to the Braudelian scheme of historical temporalities. It is well known that Braudel (1995) defined three levels of historical accounts. The topmost level is that of short-term events and individuals; the middle level comprises perennial trade cycles, whereas the bottom level describes multidecadal to centennial structures among which Braudel counted changes in climate. He played down the short-term level against the longer time-scales seeing events and individuals as the "ephemera" or "trivia" of the past. Le Roy Ladurie's concept of the Little Ice Age fits perfectly into the Braudelian "long duration" tradition. He concluded that all seasons had undergone a more or less synchronous cooling in the late sixteenth century. Likewise, he assumed that the warming from the late nineteenth century was more or less synchronous in all seasons. His book leaves the impression that there was a distinct Little Ice Age climate which was predominantly cold and rainy. Moreover the French historian impressively supported his point of view from pictorial representations of historical glaciers. The Rhone Glacier near Gletsch (Canton Valais) is perhaps the most spectacular among them. At the time of its peak expansion in 1856 it had filled the valley with an enormous mass of ice which then rapidly vanished in the subsequent period of warming. By reducing humans to the function of weather observers the French historian offered a history of climate without a human focus. Therefore, not only did he break away from the traditional topics and approaches of historiography, but he simultaneously disregarded the 
fundamental dichotomy between natural sciences and the humanities. In agreement with the Braudelian concept of historical temporalities Le Roy Ladurie concluded that "in the long term [emphasis added by C.P.] the human consequences of climate seem to be slight, perhaps negligible, and certainly difficult to detect" (Le Roy Ladurie 1971). For several decades this claim of the founding father of historical climatology served as a key argument to shun attempts to assess societal dimensions of climatic change.

At first sight, Le Roy Ladurie seems to have been right: people may adapt their way of living to a changing climate in the longer term. Innovations that are better suited to a new situation will come to be accepted, while older outdated practices may quietly disappear. However, the French historian did not argue on the appropriate level of temporalities. People are known to be highly vulnerable to short-term climate shocks known to have affected everyday life, i.e. nature-induced disasters and considerable departures, both positive and negative, from average conditions of temperature and precipitation. A history of climate and society should therefore draw on extreme events and highlight changes in the frequency of such weather spells as were recognised by contemporaries to bear the risk of widespread weather-related crop failures (Pfister 1984, 2005, 2007). In recent years, Le Roy Ladurie adopted this point of view about the human history of climate as he highlighted the impact of weather and climate on harvests and subsistence crises in the preindustrial past (Le Roy Ladurie 2004). Humans enjoy, in part, two dimensions of existence and spheres of causation, the natural and the cultural. With their bodies, humans are part of the material sphere of nature. With their minds, they are part of the symbolic sphere of culture (Sieferle 1997). Weather, rather than climate, had a prominent place in both spheres. Prior to the age of large technical systems, it was, via the foodsystem, the energy system and the risk of climate-related epidemics, a significant component in man's biological life. At the same time, it held a prominent place in people's minds (e.g. Münch 1992). Rather than smoothed temperature curves on a high level of spatial aggregation, historians working on impacts of and discourses on past climate therefore need evidence that offers a high resolution in terms of time, space and of climate elements themselves. Such detailed requirements are met in individual documentary sources on climate such as chronicles and (weather) diaries. Given this situation, historical climatologists had to develop their own approach of climate reconstruction which allows for working with data on different time scales from daily weather observations to seasonal and annual indices of temperature and precipitation (Pfister 1984; Brázdil et al. 2005).

However, data situated on both macro and micro-level are difficult to bring in line, because their temporal and spatial frameworks are to some extent incompatible. Reports on the micro level demonstrate those ways in which extreme events influenced humans and affected their decision making. However, such episodes are too fragmented to be integrated into narratives of climatic change on longer time scales. Macro-level accounts, on the other hand, provide impressive long-term surveys of climate change without, however, providing conclusive links to human history. At least, climate history on the macro level offers an interpretative framework, in which meaning may be attributed to individual climate anomalies. It matters for human perception and interpretation, as well as for measures being taken, whether extreme anomalies were episodic or whether they occurred frequently within a couple of years. 
It is hardly surprising that climate history and cultural history have until recently been written separately (e.g. Behringer 2007), even though they share a common object, which is mankind. During the last two decades, the mainstream of historiographers has moved away from dealing with the facts of material life in order to explore the promising new field of cultural history. This has been the case even in fields such as demography (e.g. Livi Bacci 1999), where climate change was previously given at least some consideration (e.g. Post 1985). Influential economic historians likewise downplayed the significance of climate (Mauelshagen 2009). For example, De Vries postulated that any test of climatic influences on economic life in general should take the form of an econometric model, which in addition to climatic data includes all the other significant variables (De Vries 1981). Given the fragmentary nature of relevant sources and their limited potential for quantification, such a concept is chimerical. There is little hope of getting enough reliable evidence to drive such a sophisticated model for a given territory. Nobel laureate Robert W. Fogel even tried to disprove any relationship between climatic extremes and famines, claiming that "famines were caused not by natural disasters but by dramatic redistributions of entitlements to grain" (Fogel 1992). Nobody is going to put the significance of entitlement failures into question, but the one sidedness of Fogels' claim remains yet questionable.

There is good reason why most historians are disinclined to tackle climate as a factor in history. Their reluctance is connected to their refusal of climatic determinism, which postulates that climatic factors have been among the greatest factors in determining the course of human history (e.g. Huntington 1924). Climate determinism is not a homogenous pattern of thought. In fact, it changed over time being connected to ever more novel theories of climate, beliefs and tendencies (Mauelshagen and Pfister 2010). Nico Stehr and Hans von Storch pointed out that in the perspective of the history of ideas most climate impact studies are products of latent or open climate determinism lingering on among natural scientists (e.g. Hsü (2000), which is in turn related to the persistence of the two different scientific cultures of natural sciences and the humanities (Stehr and von Storch 2000). In many studies, society is perceived as a black box assumed to react in a given way to outside stimuli in the form of climate impacts. In the perspective of climate impact research, the black box needs to be opened in order to investigate and understand the situation and logic of the impacted society.

Admittedly, effects of climatic fluctuations "on the course of history," are difficult to demonstrate because most of the factors include many internal processes compensating for adverse climatic effects (Kates 1985). It is frequently overlooked that both "climate" and "history" are blanket terms, situated on such a high level of abstraction that relationships between them cannot be investigated in a meaningful way in accordance with the rules of scientific methodology. On a very general level, it could be said that beneficial climatic effects tend to enlarge the scope of human action, whereas climatic shocks tend to restrict it. Which sequences of climatic situations mattered depends upon the impacted unit and the environmental, cultural and historical context. This statement needs even to be restricted in the sense that the term "climatic shock" itself is ambiguous, as it is well known that some of the people and groups involved always take advantage of situations of general distress, both economically and politically. It needs to be emphasized that investigating past climate and its significance for, and its perception by, humans does not imply as a matter of course that climate is considered to be a determinant factor. Rather, it 
is assumed that climate is among those conditions - as are population growth and wars - which may be significant in accounting for a given situation. Whether and to what extent climatic factors mattered for social vulnerability needs to be determined through empirical analyses (Pfister 2005; Pfister and Brázdil 2006).

Over the last three years future changes in climate as a consequence of global warming have jumped to the forefront of discussion all over the world. The time to meet the challenge is known to be limited. "Yet, as collective humanity we are only just beginning to take the steps needed to respond to the threats that we and the succeeding generations are confronting" (Giddens 2009). It is not at all clear, whether and how the agents-individuals, enterprises, communities, states, international bodies-will meet the enormous challenge to mitigate the impacts and adapt to the consequences of future changes in climate. In any case, the ball is in the court of societies themselves and it is to be expected, that different societies will respond in different ways to the challenge offered by climatic change. Studies of socio-environmental responses to climatic change and climatic impacts need to draw from past experience. Historical climatologists, as far as they are genuine historians, should grasp this reality as an opportunity to embark on investigations of social vulnerability to climates in the past. Such projects should not be hampered by limited data availability. Therefore "best data studies" should be conducted for the nineteenth and twentieth centuries (Mauelshagen and Pfister 2010). Of these, the "last subsistence crisis in the Western World" (Post 1977) which was triggered by the explosion of Tambora in April, 1815, would be an ideal case to draw a wider global picture (Harington 1992) which could be substantially deepened in Europe, in the United States and perhaps elsewhere. Needless to say, a universallyapplicable picture of social vulnerability to climate impacts is not to be expected from such studies. Quite the contrary: it would be worthwhile to illustrate the plurality of human responses and solutions in mitigating societal vulnerability to climate variability. Such cooperation would yield a picture of man's relation with climate which is tailored to the realities of the twenty-first century.

Acknowledgements Dennis Wheeler, Sunderland, is acknowledged for providing style corrections. Rudolf Brázdil, Brno, is acknowledged for contributing valuable suggestions.

\section{References}

Behringer W (1999) Climatic change and witch-hunting, the impact of the little ice age on mentalities. Clim Change 43:335-351

Behringer W (2007) Kulturgeschichte des Klimas. Von der Eiszeit bis zur globalen Erwärmung. Beck, München, p 352

Braudel F (1995) The Mediterranean and the Mediterranean World in the Age of Philippe II, 2 vol. University of California press, Berkeley, p 1375

Brázdil R, Pfister C, Wanner H, von Storch H, Luterbacher J (2005) Historical climatology in Europe-the state of the art. Clim Change 70:363-430

Brázdil R, Dobrovolný P, Luterbacher J, Moberg A, Pfister C, Wheeler D, Zorita E (2010) European climate of the past 500 years: new challenges for historical climatology. Clim Change. doi:10.1007/s10584-009-9783-z

Cook ER, Briffa KR, Jones PD (1994) Spatial regression methods in dendroclimatology: a review and comparison of two techniques. Int J Climatol 14:379-402 
De Vries J (1981) Measuring the impact of climate on history: the search for appropriate methodologies. In: Rotberg RI, Rabb TK (eds) Climate and history, studies in interdisciplinary history. Princeton University Press, Princeton, p 280

Dobrovolný P, Brázdil R, Valášek H, Kotyza O, Macková J, Halíčková M (2009a) A standard palaeoclimatological approach to temperature reconstruction in historical climatology: an example from the Czech Republic, AD 1718-2007. Int J Climatol 29:1478-1492

Dobrovolný P, Moberg A, Brázdil R, Pfister C, Glaser R, Wilson R, von Engelen A, Limanowka D, Halièková M, Macková J, Kiss A, Riemann D, Luterbacher J, Böhm R (2009b) Monthly, seasonal and annual temperature reconstructions for Central Europe derived from documentary evidence and instrumental records since AD 1500. Clim Change. doi:10.1007/s10584-009-9724-X

Diaz HF, Stehle DW (2007) Climate and cultural history in the Americas: an overview. Clim Change. doi:10.1007/s10584-007-9237-4

Endfield G (2007) Archival explorations of climatic variability and social vulnerability in colonial Mexico. Clim Change 83:9-38

Fogel RW (1992) Second thoughts on the European escape from hunger. Famines, Chronic Malnutrition and Mortality Rates. In: Osmani SR (ed) Nutrition and poverty. Clarendon Press, Oxford, pp 243-286

Giddens A (2009) The politics of climate change. Polity, Cambridge, p 260

Harington CR (ed) (1992) The year without a summer? World Climate in 1816. Canadian Museum of Nature, Ottawa, p 576

Hsü KJ (2000) Klima macht Geschichte. Menschheitsgeschichte als Abbild der Klimaentwicklung. Orell Füssli, Zürich, p 334

Huntington E (1924) Civilization and climate. Yale University Press, New Haven, p 453

Kates RW (1985) The interaction of climate and society. In: Kates RW, Ausubel JH, Berberian M (eds) Climate impact assessment, SCOPE, vol 27. Studies of the Interaction of Climate and Society, John Wiley, Chichester, pp 3-36

Ka-wai-Fan (2009) Climatic change and dynastic cycles in Chinese history: a review essay. Clim Change. doi:10.1007/s0584-009-9702-3

Leijonhufvud L, Wilson R, Moberg A (2008) Documentary data provide evidence of Stockholm average winter to spring temperatures in the eighteenth and nineteenth centuries. Holocene 18:333-343

Leijonhufvud L, Wilson R, Moberg A, Söderberg J, Retsö D, Söderlind U (2009) Five centuries of Stockholm winter/spring temperatures reconstructed from documentary evidence and instrumental observations. Clim Change. doi:10.1007/s10584-009-9650-y

Le Roy Ladurie E (1971) Times of Feast, Times of Famine: A History of Climate since the Year 1000, translated by Barbara Bray, Allen \& Unwin, London, 426 pp. (Original publication Histoire du Climat depuis l'an Mil, Paris 1967)

Le Roy Ladurie E (2004) Histoire humaine et comparée du climat. Canicules et Glaciers XIIIeXVIIIe siècles. Fayard, Paris, p 740

Livi Bacci M (1999) The population of Europe. Blackwell, Oxford, p 220

Mauelshagen F (2009) Keine Geschichte ohne Menschen: Die Erneuerung der historischen Klimawirkungsforschung aus der Klimakatastrophe. In: Kirchhofer A, Krämer D, Merki CM, Poliwoda GN, Stuber M, Summermatter S (eds) Nachhaltige Geschichte. Festschrift für Christian Pfister. Chronos, Zürich, pp 169-193

Mauelshagen F (2010) Klimageschichte der Neuzeit 1500-1900. WGB, Darmstadt, p 144

Mauelshagen F, Pfister C (2010) Vom Klima zur Gesellschaft: Klimageschichte im 21. Jahrhundert. In Welzer H, Soeffner HG, Giesecke D (eds) Klimakulturen. Soziale Wirklichkeiten im Klimawandel. Campus Verlag, Frankfurt/M (in press)

Münch P (1992) Lebensformen in der Frühen Neuzeit. Propyläen, Frankfurt, p 603

Perch-Nielsen S, Bättig MB, Imboden D (2008) Exploring the link between climate change and migration. Clim Change 91:375-393

Pfister C (1984) Das Klima der Schweiz von 1525 bis 1860 und seine Bedeutung in der Geschichte von Bevölkerung und Landwirtschaft, 2 vols, Haupt, Bern, 814, p 163

Pfister C (2001) Klimawandel in der Geschichte Europas. Zur Entwicklung und zum Potenzial der historischen Klimatologie. Österreichische Zeitschrift für Geschichtswissenschaften 12:7-43

Pfister C (2005) Weeping in the snow-the second period of little ice age-type crises, 1570 to 1630. In: Behringer W, Lehmann H, Pfister C (eds) Cultural consequences of the little ice age. Vandenhoeck \& Ruprecht, Göttingen, pp 31-85 
Pfister C (2007) Climatic extremes, recurrent crises and witch hunts: strategies of European societies in coping with exogenous shocks in the late sixteenth and early seventeenth centuries. Mediev Hist J 10:1-41

Pfister C, Brázdil R (2006) Social vulnerability to climate in the "Little Ice Age": an example from Central Europe in the early 1770s. Clim Past 2:115-129

Pfister C, Garnier E, Alcoforado MJ, Wheeler D, Luterbacher J, Nuòes MF, Taborda JP (2010) The meteorological framework and the cultural memory of three severe winter-storms in early eighteenth-century Europe. Clim Change. doi:10.1007/s10584-009-9784-y

Post JD (1977) The last great subsistence crisis in the Western World. John Hopkins, Baltimore, p 240

Post JD (1985) Food shortage, climatic variability and epidemic disease in preindustrial Europe: the mortality peak in the early 1740s. Cornell University Press, Ithaca, p 303

Schenk GJ, Engels JI (2007) Historical disaster research, concepts, methods and case-studies. Historical Social Research 32/3, Special Issue

Sieferle RP (1997) Kulturelle Evolution des Gesellschafts-Natur-Verhältnisses. In: Fischer-Kowalski M (ed) Gesellschaftlicher Stoffwechsel und Kolonisierung von Natur. Fakultas, Amsterdam, pp 32-56

Stehr N, von Storch H (2000) Von der Macht des Klimas. Ist der Klimadeterminismus nur noch Ideengeschichte oder relevanter Faktor gegenwärtiger Klimapolitik. Gaia 9/3:187-195 